\title{
Süveges Ildikó professzor 80 éves
}

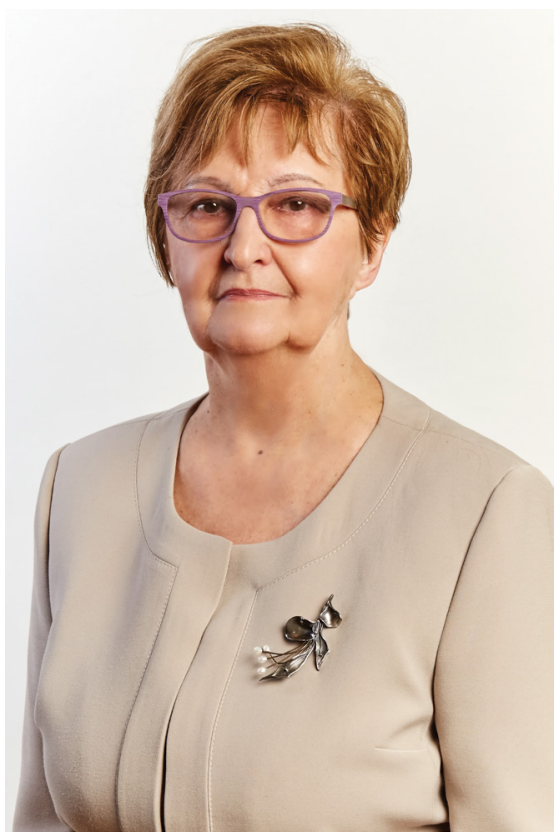

Süveges Ildikó 1939. augusztus 17-én Debrecenben születetett. Középiskolai és egyetemi tanulmányait is Debrecenben végezte, általános orvosi diplomáját „summa cum laude" minősítéssel a Debreceni Orvostudományi Egyetemen 1963-ban szerezte. Már orvostanhallgatóként is szeretett oktatni, az Anatómiai Intézetben dolgozott demonstrátorként. 1964 és 1984 között a debreceni Szemklinika munkatársa volt, először Kettesy Aladár, majd Alberth Béla professzorok mellett. 1970ben egy évig Svájcban dolgozott, a Fonds National de la Recherche ösztöndíjasaként, ahol szemészeti patológiával foglalkozott. 1979-ben Ausztriában volt állami ösztöndíjas, 1987-ben DAAD- (Deutscher Akademischer Austauschdienst [Német Felsőoktatási Csereszolgálat]) ösztöndíjasként rövid tanulmányúton a szemészeti mikrosebészeti eljárásokat tanulmányozta Németországban. 1980-ban nevezték ki egyetemi docensnek, 1974-ben lett az orvostudományok kandidátusa, 1985-ben a Magyar Tudományos Akadémia (MTA) doktora.

1984-ben Kahán Ágost professzor nyugdíjba vonulása után a szegedi Szent-Györgyi Albert Orvostudományi Egyetem Szemklinikájának igazgatójává nevezték ki, ahol 1992-ig dolgozott. 1992-ben a Semmelweis Egyetem I. Sz. Szemészeti Klinikájának igazgatói állását pályázat útján nyerte el. A nagy hírű klinikát Varga Margit professzor utódaként 2004-ig, nyugállományba vonulásáig vezette.
Hosszú évtizedeken át számos társasági és szakmairányító feladatot látott el. 1992 és 2014 között a Szemészeti Grémium, 1989 és 1997 között a Magyar Szemorvostársaság, 2001 és 2006 között a Szemészeti Szakmai Kollégium elnöke volt. Az I. Sz. Szemészeti Klinika igazgatójaként az Országos Szemészeti Intézet vezetője is volt több éven keresztül. Átalakította a Szemészet folyóiratot, gondoskodott rendszeres megjelenéséről. Vezetôségi tagja volt a Korányi Sándor Társaságnak, 1993 és 2003 között a Magyar Egészségügyi Társaság anyaországi elnökeként tevékenykedett. Az erdélyi szemészkollégák képzését és szakmai segítését szintén kiemelt fontossággal kezelte. 1985 és 1996 között tagja volt az MTA Érzékszervi Bizottságának, majd titkára az MTA II. Sz. Klinikai Mútéti Bizottságának. Az MTA köztestületi tagja. Szintén megbecsült tagja volt az Európai Szemész Patológus Társaságnak és a Német Szemorvostársaságnak. 1997-ben megrendezhette az Európai Szemész Kongresszust. Tiszteletbeli tagja a német, a finn és az ukrán szemorvostársaságnak, az Academia Ophthalmologica Internationalis választott tagja, az Európai Szemészeti Akadémiának alapító tagja, az Amerikai Szemorvos Társaságnak VIP-tagja. 1998 és 2014 között az UEMS (Union Européenne des Médecins Spécialistes [Európai Szakorvosszövetség]) Szemészeti Szekciójának magyarországi képviselóje volt, továbbá tagja volt a Societas Ophthalmologica Europaea Tanácsának. Jelenleg a Semmelweis Egyetem Klinikai Orvostudományok „Szemészet” Doktori Iskola vezetóje. Évek óta aktív tagja az Orvosi Hetilap Szerkesztőbizottságának.

Süveges professzornő nagy tudású klinikus, kiváló mikrosebész, széles körú publikációval rendelkezik. Munkássága során több mint 231 közleménye jelent meg. Az általa szerkesztett „Szemészet” tankönyv negyedik kiadása 2017-ben jelent meg. Ugyanebben az évben jelentette meg a „Negyven év szemészet a Tömő utcában" címú könyvét.

Tudományos érdeklődése kezdetben a szemészeti patológia felé irányult, a további években a szemészeti mikrosebészet, a keratoconus, a corneadystrophiák kezelése és az uveitis is figyelme középpontjába került. Sokat foglalkozott a szaruhártya betegségeinek hisztopatológiai elemzésével is, ebben a témában számos publikációja jelent meg, külföldi kongresszusok meghívottja volt.

Süveges professzornő kiváló előadó. A medikusok, szakorvosjelöltek és szakorvosok is figyelemmel hallgatták előadásait, amelyek jól követhetók, érdekfeszítők és kiválóan dokumentáltak voltak. Mindig felkészülten lépett az elóadói pulpitusra, soha nem tartott egyetlen elö- 
adást sem rutinból. Kollégáit is tudatosan készítette fel az előadások megtartására, azok tartalmát előzetesen személyesen ellenőrizte. Nemcsak a magas szakmai tartalmat követelte meg, de még az intonációt is korrigálta. Jelentős szerepe volt a szemészrezidens- és -szakorvosképzés curriculumának, követelményrendszerének megváltoztatásában és kidolgozásában.

A medikus- és szakorvosképzésen kívül a szemészeti szakasszisztensek és mütősnők továbbképzését is fontosnak tartotta. Éppen 20 évvel ezelőtt szervezte meg az első ilyen továbbképzést Budapesten, amelyet azóta minden évben megrendez a Semmelweis Egyetem Szemészeti Klinikája.

Szegeden (1984 és 1992 között) a korábban konzervatív szemléletű klinikából néhány év kitartó munkájával és következetességével az ország vezető szakmai intézményét alakította ki. Új mikrosebészeti eljárásokat vezetett be, a középvezetőket rövid külföldi tanulmányutakra küldte, bevezette, hogy a referálókat angol vagy német nyelven kellett tartani. Kiemelt feladatának tekintette egy gyermekszemészeti önálló osztály megteremtését Szegeden, amit sikeresen megvalósított. A gyermekszemészeten belül kiemelten foglalkozott a koraszülött gyermekek ROP- (retinopathia prematurorum) szövődményeinek megelőzésével, illetve azok sebészi kezelésével. Szervezőmunkáját 1992-ben fáradhatatlanul Budapesten folytatta. Felújította a Klinika sebészeti armamentáriumát, új lézerberendezéseket szerzett be, átépíttette a korszerütlen klinikai ambulanciát. Magyarországon az elsők között, 1992-ben végzett vitrectomiát, az országban elsőként szerzett be excimerlézert, így megkezdődhetett a szaruhártya fotorefraktív és fototerápiás célú kezelése. Ez az évszám azért ilyen fontos, mert az első ilyen kezelés csak 4 évvel azelőtt történt a világon; az FDA (Food and Drug Administration [az Egyesült Államok Élelmiszerés Gyógyszerellenőrzési Hatósága]) csak 1995-ben engedélyezte a módszert széles körben, ő pedig Magyarországon már 1992-től, az európai bevezetéssel egy időben elérhetővé tette a módszert. A refraktív sebészeti témájú közlemények számos hazai és nemzetközi elismerést hoztak a Klinikának; munkatársai itt írták le először az avascularis cornealis sebgyógyulás időszakában az ultraibolya-B-besugárzás káros szerepét fotorefraktív keratectomiákat követően, amely a sebgyógyulást módosíthatja, és azt a hegesedés, illetve a regresszió irányába tolhatja el.

Süveges professzornő menedzser típusú, kiváló szervező. Munkatársait megválogatta, szakmai fejlődésüket elősegítette. Témaválasztásukat tiszteletben tartva, sarkallta őket a még jobb szakmai teljesítményekre. Egyénisége dinamikus, stílusa maximalista, munkabírása kiemelkedő. Személyes példamutatásával is biztatta munkatársait még nagyobb teljesítményekre. Kiválóan és élvezetesen mesél történeteket a régi szemészeti vezetőkről, kiemelkedő szemész egyéniségekről.

1983-ban az Egészségügy Kiváló Dolgozója kitüntetést, 1993-ban a Markhot-emlékérmet, 1997-ben a Javal Gold Medalt, 1999-ben a MOTESZ- (Magyar Orvostudományi Társaságok és Egyesületek Szövetsége) díjat, 2002-ben a Magyar Szemorvostársaság Imre-Blaskovics-emlékérmét, 2003-ban a Medicina Nívódíjat, valamint a Magyar Köztársasági Érdemrend tisztikeresztje (polgári tagozat) kitüntetést, 2010-ben a Nemzeti Erőforrás Minisztériuma Semmelweis-díját, 2016-ban az Egészségügyi Tudományos Tanács Hőgyes Endre-díját, 2017-ben az Erdélyi Múzeum Egyesület Lencsés György - Ars Medica díját kapta. Kenderes díszpolgárának választották. 2004-ben a Magyar Szemorvostársaság 100 éves évfordulója alkalmából Emlékülést szervezett a Magyar Tudományos Akadémián. Ezután röviddel, 2004ben vonult nyugállományba. Azóta is aktív résztvevője a szemészeti kongresszusoknak, továbbképzéseknek. Aktivitása a régi, még közeli munkatársai sem hiszik el, hogy Professzornő a napokban betölti a nyolcadik X-et. További aktív éveket és jó egészséget kívánunk a magyar szemészet mindnyájunk által nagyra becsült ikonjának.

Nagy Zoltán Zsolt dr.

\author{
„A szem a lélek tükre, és ha Isten segítségével \\ sikerül valakinek a szemvilágát is visszaadnom, \\ akkor rendszerint a lelkére is tudok hatni." \\ (Batthyány-Strattmann László)
}

